\begin{tabular}{|c|c|}
\hline & $\begin{array}{l}\text { International Journal of Trend in Scientific } \\
\text { Research and Development (IJTSRD) }\end{array}$ \\
\hline $\begin{array}{lll} & \end{array}$ & International Open Access Journal \\
\hline 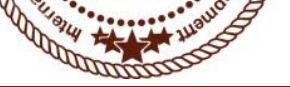 & ISSN No: $2456-6470 \mid$ www.ijtsrd.com | Volume - 2 | Issue -4 \\
\hline
\end{tabular}

\title{
A Pragmatics analysis of the phrases used by Former Prime-Minister Dr Manmohan Singh in his speech: A Case study
}

\author{
Syed Umer Ahmad Qadri (PhD) \\ Department of Linguistics, (Lamm) \\ Aligarh Muslim University, Aligarh, Uttar Pradesh, India
}

\begin{abstract}
Now a days in politics, there is extensive use of the phrase. This study focuses on the pragmatics use of languages in politics. People express more than they are saying or express a specific which means has a meaning. People perform varied of acts through speech. The competency with which state-of-affairs is handled is thought as "pragmatics competency. The information for pragmatics comes from day-to-day speech, employed by the user of language in several contexts. The study analyses pragmatic expression of former Prime Minister of India, Dr. Manmohan Singh expressed in the Indian Parliament while discussing demonetization. The study is based on discourse analysis.
\end{abstract}

Keywords- Pragmatics, Analysis, situation, Social, Phrase, Context, Slogans, sign (+++), (++)

\section{INTRODUCTION}

This paper analyses the two phrases/slogans at the extent of lexical level, pragmatic level and the perception level used by Dr. Manmohan Singh in two completely different purpose of time. Oxford dictionary defines; Slogan as a short and striking or memorable phrase used in promotion. Pragmatics is the sole field of linguistic analysis for troubled with humans and their (verbal and non-verbal) interactions. This inevitably poses a series of issues that decreases or increases depend upon the degree of familiarity between the speaker and the listener.

(Yule. G 1996) opines that the relative distance between the speaker and the listener: the near of the gap between speakers, (e.g. A well-recognized social group), the additional victorious their interaction. According to "Charles Morris's, pragmatics is "the study of the relation of signs to interpreters". In an exceedingly fashionable, communication-oriented language, we have a tendency to opt to cite 'messages' and 'language users'; in distinction to ancient pragmatics, that initial and foremost concentrates on the weather and structures, like sounds and sentences that the language users turn out, pragmatics focuses on the language-using humans.

In other words, Pragmatics is the study of hidden expression used by a spokesperson in his speech. Pragmatics studies, language that is not spoken directly. The spokesperson indicates or suggests a meaning, and listeners presume the intentions. Pragmatics is seen as an understanding between people to comply with certain rules of interaction. In everyday language, the meanings of slogan or phrase are constantly oblique and not unequivocally stated. In certain situation phrase or slogans can have certain meanings.

It is the study of choice we make when we use language - the intentions that lie behind our choices, and the effect our choice convey. The structural level focuses on what and how of the language; pragmatics focuses on why. It provides an explanatory perspective for language use. (David C., 2011)

Pragmatics might be a methodical approach of explaining language use in a context. Each context incorporates a special meaning and it's the context that decides what it means. Therefore, what it means is set by the relative quality of language used and also the intention of speaker to listener. After we say relative distance, it means that however shot or distant someone is with another person and the way language expresses this distance. Pragmatics is that the study of what the speaker means that by locution one thing and what the listener understands once one thing is alleged or however, will a speaker use language in an exceedingly specific 
context and the way it's understood within the use of same context. The primary necessary factor that has got to be done is to draw a distinction between the means, of sentences and also the means of utterances.

The role of context is usually necessary within the study of the use of pragmatics. Pragmatics studies, the ways in which context affects the meaning. The two primary styles of context essential to pragmatics are 'linguistic context' (the context of language) and 'situational context' (the context of the situation). Discourse precedes the phrase or sentence to be understood, whereas the situational context includes data of the world; together with the speaker, the hearer, third parties and their beliefs.

The chore of pragmatics is to study, however, people express more than they are saying or express a specific which means. It tries to check however, people perform varieties of acts through speech. The three important areas in pragmatics are: the study of speech acts, politeness principle, and also the colloquial principle. Pragmatics is additionally involved with the management that's however, people manage totally different varieties of things. The competency with that a state of affairs is handled is thought as 'pragmatic competency.' the information for pragmatics comes from day to day speech, employed by the user of language in several contexts.

According to Noam Chomsky in his Rules and Representations, "Pragmatic competence is the one that underlies the ability to use language along with the conceptual system to achieve certain ends or purposes" and it determines how the tool can be effectively put to use; it is user-oriented. (chomsky.N, may-2005).

Slogans; Slogans are a memorable phrase used in a clan, political, government, and other context as a repetitive expression of an idea or purpose, with the goal of persuading members of the public or a more defined target group.

Slogans consist primarily of unconventional words or phrases that categorical either one thing new or one thing previous in a very new means. It should be frivolous, irreverent, and indecorous; it might even be indecent or obscene. Its vibrant metaphors square measure usually directed at honorableness, and it's the summary, typically humorous, often impertinent social criticism that provides slogans its characteristic flavor. Slogans, then, include not simply words; however words utilized in a special means in a very certain social context. The common divisor is that each one these phrases promote a cause, idea, ideology

\section{METHODOLOGY}

The methodological framework during this paper attracts on important discourse analysis as formed by its greatest theoretician NS (Fairclough 1992, 1995a, 1995b, 2001a, 2001b, 2003; Fairclough and Wodak 1997; van Dijk 1997, 1998, 2001, 2008; Chilton and Schäffner 1997; Chilton 2004) and it's a mixture of assorted approaches custom-made to the corpus and therefore the aim of analysis. SA is developed from an important theory of language that depicts language as a way of social follow that square measure all certain with sure historical contexts (Janks, 1997). SA provides theories and strategies for empirical studies of the relations between discourse and social and cultural developments in numerous social domains. In step with Jorgensen and Phillips (2007) there square measure multiple investigations of SA that all verify the options of the linguistic analysis.

\section{A. Data assortment}

The material studied in this paper was extracted from the speech of former Prime Minister Dr Manmohan Singh used two slogans in his speech.

* First Phrase was used in Rajya Sabah.

* Second Phrase was used outside the parliament on the controversial coal block allocations. 


\begin{tabular}{|l|}
\hline "Monumental mismanagement, \\
"Organized loots and legalized plunder"
\end{tabular}

And

"Hazaaron Jawabon Se Acchi Hai Meri Khamoshi"
Na jane kitne sawalon ki aabru rakhe.
Translation
My silence is better than a thousand answers, it
keeps unbroken the honor of untold questions

For the current study, both paradigms are used for the complete understanding of Dr Manmohan Singh's discourse. The character of social and cultural processes and structures is partially linguistic- pragmatics.

\section{B. Critical Analysis}

The analysis first establishes the social observe, that is, however, numerous social, economic, political and different phenomena manifest themselves in discourse and the way some slogans will influence and even trigger some changes in society, the interpretation of discourse happens at two levels (Fairclough 2001a): the amount of context and therefore the level of text. At the discourse level, we tend to mention the worldwide and native situational.

\section{Monumental mismanagement, \\ "Organized loots and legalized plunder"}

Lexical analysis is the process of learning more about words expression by studying their origin and part.

\section{Analysis at level of lexical}

The word monumental is an adjective and its expression as 'resembling a monument; massive or imposing. The words come from the Latin word "monumentalise", dating back to 1595-1605.

The word Mismanagement consists with prefix (miss-) and suffix (-ment) which creates negative sense and manages words comes from Italian maneggiare.

The word organized comes from the Latin organizare and first used in around 1375-1425.

The word loot comes from middle ditches loet, loete.

The word legalized first recorded in 1710-20 consist with verb (legal) + suffix ( ize)

The word Plunder from German plunder in mid $17^{\text {th }}$ century.

\section{Analysis of the phrase expression}

The phrase employed by Dr. Manmohan Singh includes a ton of pragmatic sense. He used as info regarding future's financial condition of the Republic of India what currently exist. This phrase makes pragmatic sense as BJP has no experience in governance and leaders of BJP have no any expertise and no how to run the country.

Note- According to Steve-jobs co-founder Apple "thinking of Indian people a limited. He explains that when people of India think of progress and getting good marks in their studies and getting a job as a sign of successes and progress. 
International Journal of Trend in Scientific Research and Development (IJTSRD) ISSN: 2456-6470

Analysis of the perception of the phrase, organized loot and legalized plunder"

Table 1

\begin{tabular}{|l|l|l|l|l|}
\hline Venue & Context & Hearer & $\begin{array}{l}\text { Perception/ } \\
\text { Understanding }\end{array}$ & Result \\
\hline Parliament & Demonetization & $\begin{array}{l}\text { Peoples of } \\
\text { India and } \\
\text { world through } \\
\text { The Media. }\end{array}$ & $\begin{array}{l}\text { Intellectual (+++) } \\
\text { Educated (+) } \\
\text { Rest (-) they don't } \\
\text { Understand yet. }\end{array}$ & $\begin{array}{l}\text { In long } \\
\text { term. }\end{array}$ \\
\hline
\end{tabular}

The above table shows the level of understanding and thoughts of people in the country regarding slogan used by Dr Manmohan Singh. I asked direct questions to Professors, scholars, student and middle class people.

Q.1- What is the unembellished expression of the phrase used by Dr Manmohan Singh?

Q.2- What is the comprehensive expression of the phrased used by Dr Manmohan Singh?

Q.2- Why he used it?

Q.3- When he used it?

The answers were surprising. People who are involved in social and political activity answered correctly, whereas all those who were not involved in social and political activities did not comprehend it correctly. Some claimed to be very intellectual, but were unable to answer my question.

At the table (+++) sign refers to the people who understand in the right way. I found the appropriate answer of my questions from him.

$(++)$ sign refers to the people who do not comprehend fully. They were right partially.

(-) The sign refers to the people who don't know anything about it.

\section{Analysis of the phrase at the lexical level}

\section{"Hazaaron Jawabon Se Acchi Hai Meri Khamoshi}

Na jane kitne sawalon ki abru rakhe"

\section{Translation}

Silence is better than a thousand answers; it keeps unbroken the honor of untold questions.

The word "Hazaro" means that thousands, Jawabon uses as "answer" "Se" is verb here "Acchi" is an adjective here "Meri" is stands for mine, Khamoshi expression is quiet. $\mathrm{Na}$ is verb. Jane is adjective, sawalon means question.

\section{Analysis of the Phrase expression}

Another phrase used by Dr Manmohan Singh on Coal block allocation issue. This phrase was used by Dr Manmohan Singh outside the parliament. He tries and signals to the leader of BJP. I have a lot of incriminating evidences against BJP and their leader.

\section{Analysis of the understanding of people'}

\section{Hazaaron Jawbone Se Acchi Hai Meri Khamoshi,}

na jane kitne sawalon ki abru rakhe. 
International Journal of Trend in Scientific Research and Development (IJTSRD) ISSN: 2456-6470

Table: 2

\begin{tabular}{|l|l|l|l|l|l|}
\hline Venue & Context & Situation & Hearer & Perception & Result \\
\hline Parliament & $\begin{array}{l}\text { Coal block } \\
\text { allocation } \\
\text { issue }\end{array}$ & $\begin{array}{l}\text { Disrupt } \\
\text { proceedings of } \\
\text { parliament }\end{array}$ & $\begin{array}{l}\text { Members } \\
\text { parliament \& } \\
\text { Indian people } \\
\text { through media }\end{array}$ & $\begin{array}{l}\text { Anger's PM DR. } \\
\text { Manmohan } \\
\text { SIngh }\end{array}$ & $\begin{array}{l}\text { Opposit- } \\
\text { ion silent. }\end{array}$ \\
\hline
\end{tabular}

\section{FINDINGS AND RESULTS}

The speech will be otherwise be mundane if one does not read it from a linguistics perspective while not trying to research and discover the hidden messages and ideologies behind every and each verbalized word. While this is not a scrutinized analysis of the speech, as mentioned within the analysis section, the slogan is extremely pre-suppositive. Throughout the analysis of the slogan, multiple ideologies were detected and analysed. The analysis targeted solely on the foremost, greatest ideologies within the slogan.

Addressees ought to remember of what they hear, they're asked to assume before they believe, to contemplate before they react, and finally to understand that every and each auditory communication same is claims for a purpose, it's their role to seek out these functions, check its believability and influence on them and so they're unengaged to follow or to refuse it.

\section{CONCLUSION}

The slogan used by Dr Manmohan Singh is of very high level of pragmatic sense. Peoples are unable to understand its meaning without proper help by linguist or expert. The role of context is typically necessary among the study of the use of pragmatics. Pragmatics studies the ways that during which context affects which implies. The two primary varieties of context necessary to pragmatics are 'pragmatic context' (the context of language) and 'situational context' (the context of the situation). The expression is analysed at three different levels, at the level of the common man, at the level of educated masses and at the level of expert masses. The study finds that expression used by Dr Manmohan singh is very difficult to comprehend for the common people. They seem the miss the heart of the meaning of the expression and find difficulty to understand its spirit and context. The educated masses understand the meaning of the expression, but fail to understand its context. Further educated masses miss the core pun of the expression, they believe it's a great statement, but find difficult to comprehend the severity of long term impact on the economy. The expert audiences having a sociopolitical and economic background are fully able to comprehend the expression and understand the metaphor, pun, and sincerity of the context in imbibed in the expression. Thus, the expression used by Dr Manmohan Singh has very limited impact.

\section{References}

[1] Birner, B. J. (june-2012). Introduction to Pragmatics. In B. J. Birner, Introduction to Pragmatics (p. 344). John Wiley \& Sons.

[2] Capone, A. (nov-2016). The Pragmatics of Indirect Reports: Socio-philosophical Considerations. In A. Capone, The Pragmatics of Indirect Reports: Socio-philosophical Considerations (p. 364). Springer International Publishing.

[3] chomsky.N. (may-2005). Rules and Representations. In chomsky.N, Rules and Representations (p. 368). Columbia University Press; Columbia Classics edition edition.

[4] Crystal, D. (2006). Language and internet; The Pragmatics Encyclopedia. In D. Crystal, Lanhuage and internet; The Pragmatics Encyclopedia (p. 234). cambridge university press.

[5] Cutting, J. (jul-2005). Pragmatics and Discourse: A Resource Book for Students. In J. Cutting, Pragmatics and Discourse: A Resource Book for Students (p. 187). Routledge. 
[6] fairclough, N. (1989). language and power. newyork: longman .

[7] Grundy, P. (1995). Doing Pragmatics. In P. Grundy, Doing Pragmatics (p. 216). E. Arnold.

[8] KenHyland. (ctober 1998 October 1998). Persuasion and context: The pragmatics of academic metadiscourse. Journal of Pragmatics , 437=456.

[9] Levinson, S. C. (Jun-1983). pragmatics. In S. C. Levinson, Pragmatics (p. 434). Cambridge University Press.

[10] Morris, C. W. (1970). The Pragmatic Movement in American Philosophy. In C. W. Morris, The Pragmatic Movement in American Philosophy (p. 210). George Braziller.

[11] MYERS, G. (march-1989). The pragmatics of politeness in scientific articles. Applied Linguistics , 135.

[12] Qadri, s. u. (april-2018). A discourse analysis of PM Modi's speech on swach bharat abhiyan. Journal of emerging technologies and innovative research , 673-677.

[13] qadri, s. u. (2018). A linguistics analysis of jawaharlal Nehru's tryst with destiny speech . Language in india , 327-337.

[14] qadri, s. u. (2017). indian slogans:A semio-communicative analysis. interdisciplinary journal of linguistics , 207-210.

[15] Yule, G. (Jun-1996). pragmatics: Foreign Language Study. In G. Yule, pragmatics: Foreign Language Study (p. 138). OUP Oxford. 